$\mathrm{UDC}-811.111^{\prime} 42$

\title{
BIRTH OF A SURREAL IMAGE IN ATTRIBUTIVE CONSTRUCTIONS
}

\section{PRADIVLIANNA L.}

Candidate of Philological Sciences, Doctoral student National Pedagogical Dragomanov University, Kyiv lyu2005pra@gmail.com

Introduction. The article focuses on the problems of the surreal images in the poetry of David Gascoigne - one of the leaders of surrealist movement in Great Britain.

Surrealist image remains a complex phenomenon with weird, fantastic, dream-like qualities. To create surreality, it must conform to rigid criteria of juxtaposing distant realities.

Purpose of this paper is to define the types of semantic connections between the elements in the adjective/participle-noun constructions in Gascoigne's poetry and to analyze the linguistic mechanisms of creating a surreal image.

Methods. The research was carried out by means of the methods of structural, semantic and contextual analysis.

Results. Despite the fact that British surrealism was less automatic than the French original, the poems of David Gascoyne show the avant-garde tendency to the liberation of the language from the established norms and freeing the poems of narrative contexts. Reading surrealist poetry involves constant and systematic decoding of strange, sometimes absurd, often violent images.

The paper looks at various types of adjective-noun constructions in Gascoigne's poetic collection created both in accordance with the system of the language and by its violation, and analyses the ways of rendering the unconscious and creating the surreality.

Conclusions. Analyses of adjective/participle-noun combinations shows the mechanisms of image creation the poet uses in his works - expressions with literal meaning in inappropriate, metaphorical, hallucinatory contexts where they acquire new semantic shades of meaning, and combinations of lexemes that belong to incompatible semantic groups. The most complicated surrealist images are born of the interlocking of several tropes or are the product of the poet's appeal to dream-like states and his contacts with the artists. The links of meaning in these wordcombinations are hard to find, which doesn't lead to the destruction of the image but inspires readers' spontaneous associations.

Key words: surrealism, image, adjective-nominative constructions, David Gascoigne.

\section{НАРОДЖЕННЯ СЮРРЕАЛЬНОГО ОБРАЗУ В АТРИБУТИВНИХ КОНСТРУКЦІЯХ}

ПРАДІВЛЯННА Людмила Миколаївна кандидат філологічних наук, докторант Начіональний педагогічний університет імені М.П. Драгоманова lyu2005pra@gmail.com

Bcmyn. Статтю присвячено проблемі вивчення механізмів створення сюрреального образу в поезії Девіда Гаскойна - одного з лідерів сюрреалістичного руху у Великій Британії. Сюрреальний образ $є$ складним явищем з ознаками дивного, фантастичного, мрійливого, що утворюється при зіставленні максимально віддалених реалій та відповідає жорстким критеріям.

Mema статті - виявити типи смислових зв'язків між компонентами ад'єктивнономінативних конструкцій у поезії Гаскойна та проаналізувати механізми створення сюрреального образу.

Meтоди. Дослідження виконано із застосуванням методів структурно-семантичного та контекстуального аналізу. 
Результати. Незважаючи на те, що британський сюрреалізм був менш автоматичним, ніж французький оригінал, у поезіях Гаскойна чітко простежується авангардна тенденція до звільнення мови від установлених норм та збільшення складності самої поезії. Читання сюрреалістичної поезії передбачає постійне і систематичне розшифрування дивних, інколи абсурдних, часто насильницьких образів. Особливу сюрреальність створюють мотиви сну та метаморфози людей, предметів і природних елементів.

На матеріалі збірки Гаскойна розглянуто види ад’єктивно-номінативних конструкцій, що побудовані як відповідно до системи мови, так і з іï порушеннями, та проаналізовано механізми створення ефекту сюрреальності й отримання доступу до несвідомого.

Висновки. Девід Гаскойн використовує два типи зв'язків у своїх поезіях словосполучення з буквальним значенням у невідповідних, метафоричних, галюцинаторних контекстах, де вони набувають нових відтінків сенсу, та сполучення лексем, які належать до несумісних семантичних груп. Найскладніші сюрреалістичні образи народжуються від переплетінь кількох тропів або $є$ продуктом впливу на поета сюрреалістичної естетики мрій і сновидінь та його зв'язків із художниками. Ланки сенсу або спільні семи в цих словосполученнях важко знайти, хоча це не призводить до руйнування образу, але надихає читача до спонтанних асоціацій. Гаскойн.

Ключові слова: сюрреалізм, образ, ад’єктивно-номінативні конструкції, Девід

Introduction. The experience of reading surrealist poetry, simply put, involves constant and systematic deciphering of strange, sometimes absurd, often violent images set in the illogical contexts. Dreamlike motives, metamorphosis of humans, objects and natural elements, which seem real and mysterious at the same time, create surreality, marvelous and bewildering, and mark this inter-war avantgarde movement.

Having established itself in numerous manifestoes and declarations as an experimental poetry, "research into human conditions" (Stockwell, 2012, p. 49), surrealism was an "attempt at a method for accessing the true nature of human perception" (Ibid.). Inspired by S. Freud's discoveries in psychoanalysis, surrealists proclaimed their belief in the powers of the unconscious - reality, greater than the rational one, sought to reach it by means of automatic writing and reveal in their poetry through specific imagery. Surreal image thus was assigned "the role of privileged vehicle for bringing forth into the conscious mind the creative forces of the unconscious" (Quinn, 1985, p. 3) and the poets were given the part of "simple receptacles of so many echoes, modest recording instruments" (Breton, 1972, p. 27-28) of images of "the supreme reality" (Ibid, p. 37).

The definition of the surreal image, offered by the leader and one of the founders of surrealism Andre Breton in First Manifesto of Surrealism (1924), was borrowed from the poet Pierre Reverdy: "The image is a pure creation of the mind. It cannot be born from a comparison but from a juxtaposition of two more or less distant realities. The more the relationship between the two juxtaposed realities is distant and true, the stronger the image will be - the greater its emotional power and poetic reality" (Breton, 1972, p. 20). The example of such image was taken from another French poet - predecessor of surrealist practices - Comte de Lautreamont: "As beautiful as the fortuitous meeting of a sewing machine and an umbrella on an operating table" (Ibid, p. 275).

To create such an image the poet has to relax into a meditative state in which - in E.B. Germain's words - he "finds himself possessed by something other than his conscious ego, by a desire that would speak - often in revelatory tones" $(1986$, p. 76) and write down his thoughts quickly and without interference of the overactive mind.

In their experimentation with this method of writing and the content of the poems the surrealists revolutionized the poetic language, bringing forth, quite accidentally, new discoveries in the poetic form. For if the rational reality is expressed through a conventional language system, the new 'surreality' needed the language of its own. 
Unfortunately, having set a paragon for a surreal image, Breton didn't elaborate on it, hence so much reluctance and doubts regarding the approaches to the study of its linguistic constituents. And though the image is the core concept of surrealist poetry, its complexity and, more often than not, absurdity and arbitrariness restrain the researchers who tend to "avoid direct confrontation" with it (Quinn, 1985, p. 3).

This paper aims to look at only one facet of a surrealist verse - the structure of poetic image, namely attributive "adjective/participle - noun" constructions, and, in an attempt to find the connecting links of meaning, will analyze the linguistic mechanisms of blending "juxtaposed and distant realities" into a holistic image.

Analysis of recent publications. It should be noted that surrealist image has been an object of quite a few studies which demonstrate different approaches to this phenomenon.

Thus, Shelley Quinn in a $1985 \mathrm{PhD}$ thesis on surrealist imagery appeals to the discoveries in the fields of neurology, psychology and psycholinguistics. The researcher endeavors to "destroy the myths surrounding the movement" (p.12) and demonstrate that "surreal imagery need not, and indeed should not be read as an expression of the poet's subconscious" (Ibid, p. 268). She argues that "Breton's unconscious appears to be closely related to the neurologists' right hemisphere" (Ibid, p. 22). Surrealists searched for the ways to liberate their cognitive processes from rational thought and "rational" language and so experimented with the states where "analytical" left hemisphere's activity, responsible for verbal expression, was reduced to give way to and enhance activities of a more creative and "visual" right hemisphere.

Whereas we find it hard to dispute with Shelley Quinn, who, by the way, acknowledges "the very hypothetical nature" of the explanations offered in her work (Ibid, p. 268), we still find her classification of major imagery types, based on the hemispheric dominance, of great interest. In the historical survey from Romanticism to Surrealism, the author observes the move away from normative perception expressed in a combination of literal and figurative modes (left hemisphere images) towards more abstract verbalization of thoughts, dream imagery, and a greater visuality of the "right hemisphere dominant" automatic and homospatial writing of surrealists.

In another survey - from Baudelaire and Rambo to Paul Eluard - G.D. Martin also observes the increase in the complexity of poetry. Taking a linguistic approach to the study of imagery in his article on surrealist adjectives, the researcher uses exact linguistic methods to propose strict criteria for measuring "surrealist distance" proclaimed in the image definition. His classification of images is based on the "intrinsically contrastive nature of language" (1986, p. 12). The distance is short if the lexical elements (adjectives, participles, nouns) constituting the image can be combined naturally and literally or have plausible interpretation (Martin calls it 'relatively consonant uses'). It is greater if lexemes in word-combinations apply to inappropriate domains ('dissonant uses') or are found in symmetrical/asymmetrical oppositions (connecting lexemes in oppositions along the same or different semantic groups). He also defines the level of "destruction of the literal" and "syntactic illogicalities" (Martin, 1986, p. 27-28).

Comparing surrealist texts with the poetry of their predecessors G.D. Martin notes a marked progression "in the direction of increased asymmetry, increased dissonance, and an increased 'hallucinatory' effect" (Ibid, p. 17). However, despite the distance between the juxtaposed elements of the image being sometimes pushed to considerable length, the author concludes, the images in surrealist texts are never entirely irrelevant and still preserve links of meaning without which surrealist tension and puzzlement could not be aroused. "Total dissonance [...] is totally ineffective" (Ibid, p. 26).

In his article G.D. Martin limits himself to discussion of several types of attributive constructions. A wider research on the structure and semantics of the image in the poetic texts of the French surrealists was conducted by the Russian scientist E.L. Spasskaya (1992). She takes cognitive linguistics approach supplemented by lingvo-stylistics and lingvo-poetics to define the peculiarities 
of a surreal image. The author observes that the semantic conflict which gives birth to a surrealist image occurs on the "macrogeneric level" which connects lexemes of different semantic domains. She also comes to the conclusion that a typical surrealist image is defined not by the language system but by the text and analyzes various types of transformations (lexical, phonetic, syntactic) as the means of surrealist image creation.

All classifications, made on the material of French surrealist poetry, in spite of different approaches to the texts, show the surrealist tendency to "a higher degree of dissonance" (Martin, 1986, p. 22), to increased liberation of the language from the established norms. As Andre Breton famously asserted: "The language has been given to man so that he may make Surrealist use of it" (1972, p. 32). Whether it is only the French language that has the potential for surrealist expression and creating surreality is still the question for discussion.

On the whole, in spite of almost a 100-year long history of surrealist studies, not much research has been done on the language of surrealism. One of the possible explanations might be that scientists have not arrived at a common opinion regarding the question whether it is possible to rationally interpret what was created as a hymn to the irrational, whether it is ethical "to break their works into fragments and ascribe to them meanings developed by the intellect" (Jaiocha, 2016, p. 85). Peter Stockwell - a stylistician and the author of the recent 2017 publication on "The Language of Surrealism" writes: "any attempt to analyze, interpret, or account for the textual mechanics of such works is somehow itself inimical to the spirit of surrealism" (p. 21). At the same time, Stockwell recognizes the potential of linguistics in such studies and postulates that "surrealism is as accessible to stylistic analysis as any sort of literary text" 2012, p. 54). He acknowledges though that the surrealists themselves would have condemned him for such an academic approach.

Following those researchers who 'dared' to approach surrealist image in an attempt to observe the ways the language functions when it verbalizes unconscious (or right-hemisphere) impulses expressed in the new surrealist poetic forms, we will, given the space of the article, look at a very narrow aspect of the image - adjective-noun constructions in the English language and, using linguistic methods, try to analyze and classify the mechanisms which give birth to a surreal image.

The material of our study is the collection of poetry by David Gascoyne - one of the leaders of the British surrealist movement in 1930s, the author of First English Surrealist Manifesto (1935) and $A$ Short Survey of Surrealism (1935). In these documents he states that surrealism "is by no means wholly the product of previous French culture" (1936, p. 132-133) and claims that "there is a very strong surrealist element in English literature" quoting Shakespeare, Marlowe, Swift, Young, Coleridge, Blake, Lear and Carroll "to prove the connection" (Ibid.).

Results and Discussion. The research into Gascoyne's poetic style was undertaken mostly in the UK and the US (works of Rob Jackaman, Peter Stockwell, J.H. Matthews, R.L. Scott, M. Plumbley and others). In our previous publication on surrealist lingvo-poetic experiment we made at attempt to outline phonetic, semantic and syntactic peculiarities of surrealist techniques in David Gascoyne's poem And the Seventh Dream is the Dream of Isis - in Michel Remy's words - "the first surrealist work written in English" (1999, p. 32). The author creates surreality by focusing on the visual effects, building a specific dream-like world by putting ordinary objects or people into puzzling surroundings and forcing them to do things contrary to common sense. Lexical and phonetic repetitions, intonation and metric-system shifts in which lexemes acquire new semantic load and 'signal' additional meanings are characteristics of Gascoyne's poetry (Pradivlianna, 2019).

The type of attributive constructions we look at in this paper - adjective/participle + noun is the strongest and the closest syntactic connection in the language system (Gasparov, 2012, p. 13). Quite a big number of adjectives in such word combinations in Gascoyne's poetic collection (1965) preserve natural and literal meaning - "consonant use", in Martin's terminology, and form compatible connections with nouns. Some of such constructions have a narrative or discursive context quality: 
Goliath plunges his hand into the poisoned well (p. 21), the year is full of unforeseen happenings (2012), ...offer themselves to unfrocked priests (2012), a large cocoa-tin full of shapeless lumps of wax (2012), doors fall off their hinges in ruined cathedrals (2012). As is typical for these constructions, emotive vocabulary is often observed: a winsome young girl (p. 14), the gruesome slum-visitors (2012), there is a horrible dentist walking out of a ship's funnel (2012). Such word combinations, taken out of the context, do not create surreality and can be seen practically in any poetic work of any poetic period.

The dream-like atmosphere appears when consonant word combinations are used in strange and unusual contexts: an extremely unpleasant odor of decaying meat / arising from the depetalled flower growing out of her ear (2012), white curtains of tortured destinies (2012).

This seems to be the case with many surrealist images. Simon Karlinsky in his study of surrealism in twentieth-century Russian poetry gives the following criterion for defining the surreal imagery: "If the bizarre and unusual placed in believable or prosaic surrounding make a romantically fantastic impression, the effect of the prosaic and the believable placed within a bizarre or incongruous context is [...] likely to be surrealistic" $(1967$, p. 607).

Thus, apparent simplicity and normativity of consonant adjective-noun constructions is compensated by their use in illogical similes: when hearts of troubadours unfold like soaked mattresses (2012), incongruous surrealist contexts: he knocked the fragile statue down / and ate her sugar head (p. 14), constructions with of: petals of whirling flame (p. 21), ... and then light a magnificent bonfire of old rusty nails... (p. 25). The latter type of constructions is especially powerful as they combine impossible objects, not just give dissonant attributes to them - like 'high style' expression with emotive adjective of positive semantics magnificent bonfire collides with a mundane old rusty nails with a possible link - the bright color of the fire and rust.

This is especially the case when the author connects lexemes of concrete and abstract semantics. The resulting metaphoric image enhances visuality of an abstract concept, as for instance in white curtains of infinite fatigue (2012) where psychic phenomenon of fatigue, on the one hand, acquires semantic shades of meaning attributed to it in the adjective infinite - "very great, and seeming to have no limit" (Macmillan), and, on the other, is semantically enriched through the word combination white curtains which calls for very personal associations caused by both the symbolic nature of the color white and the visual semantics of the word curtain.

It should be noted that such word combinations also increase the complexity of the image, as it is often hard to differentiate, which element is metaphorized, as in the example: divided terrain of anguish (p. 8).

The same mechanisms are used in the attributive constructions with the adjectives of color semantics. Consonant uses are quite rare: white birds fly across the ocean (2012) and most of them appear in the weird contexts: ...to engrave the foreheads of their footmen with purple signs (2012); almost impressionistic: and salt turns a pale violet color every day at seven o'clock (2012); intensifying the metaphoric image: ... and coal-black Hate / Paused on the edge of the cliff ( $\mathrm{p} .14)$, sometimes artistic, like a rich brushstroke of a painter, and also Freudian: the rainbow-colored barque of pleasure (p. 19).

Actually, erotic and violent contexts are typical for surrealist practices. In the example fumes of sulphur envelop the houses of ill-fame / out of which bloodred lilies appear (2012) negative connotation of the first line - visual and olfactory (sulphur - "a yellow chemical element that has a strong smell" (Macmillan)) is made even stronger with the word combination bloodred lilies (lily in this context probably represents "a male symbol, symbol of erotic love" (Roshal, 2008, p. 764-765) and with an attributive of color semantics bloodred actually creates a powerful associative image of violence).

Let's look at one more example of a violent image which is born out of the relatively consonant use of adjective in a metaphoric context: the night grew like a savage plant / With daggers for its 
leaves and scarlet hearts / For flowers (p. 15). Comparisons like this are not typical for French surrealist poetry and, to our mind, reduce surrealistic effect as the readers can easily connect the growing night with a plant, the savage plant - with the thorns which look like daggers and the flowers might have the form of the hearts. And it is perhaps only the collision of dagger and an attribute scarlet that gives an extra layer of meaning to these lines giving rise to new associations of savage night and scarlet/ bloody daggers.

A certain increase of the distance between the semantics of an adjective/participle and a noun in the attributive combinations can be observed in relatively consonant metonymic constructions: the draperies / Drawn back by rigid hands (p. 37) - adjective rigid applies to a person who drew the draperies; similarly: the restless traffic of the quays (p. 14), white curtains of tortured destinies (2012). The latter example presents a beautiful surreal image composed of the metaphoric opposition of tortured destinies (metonymic expression where abstract notion of destinies stand for people) and white curtains - word combination of concrete semantics which visualizes the abstract, on the one hand, and calls for individual associations, on the other.

More complex are dissonant uses of adjectives/participles in the attributive constructions (here we again use the terminology of G.D. Martin). These are expressions with the components which are opposite in meaning or belong to different semantic groups and are usually incongruous. The opposition in meaning can go along a single dimension: the tale of his bright night (p. 37) (night is supposed to be dark, not bright - hence the enhancement of the image with the implicit attributes - starry, with a full moon), the light of the stars is attracted by transparent flowers (p. 25) (both - adjective and noun are words of visual semantics but the solid objects - flowers acquire not typical characteristics: one can look through them). Similar oppositions - visual: waking night (p. 15), round his slumber are drawn back/The rigid draperies (p. 26); auditory: a dim world uttering a voiceless cry (p. 12), kinesthetic: a blossom scattered by motionless wind (p. 12).

The poet may also combine incompatible lexemes into associative image: And ant-eaters'skiingshoes / Which follow the glistening murders as far as the pond (p. 25). It's hard to find rational connection between the elements of this attributive combination (where glisten - "shine because it is wet or covered with oil" (Macmillan)). E.L. Spasskaya, however, thinks that in the surreal expression the common seme might be absent and this will not lead to the destruction of the image but will offer additional potential for the reader's interpretation (1992, p. 138-139). Examples of such images will include: the strongest canonical wastepaper-baskets (p. 25), Her shadow falling on the hungry stones (p. 14), savage pretense of knowledge (p. 8), the fevered breath of logic (p. 8).

The lexemes in such word combinations not only belong to different semantic groups, their meaning can't be deciphered from the context. Karlinsky explains: "a genuinely surrealistic type of fantasy resists any kind of paraphrasable explication and excludes any possibility of allegorical interpretation" (1967, p. 607). The reader can exercise his association skills or just relax and try to perceive this poetry emotionally, letting the images arise and chase each other spontaneously in his/her mind.

Thus we can talk about the birth of surreality in the images like: Once flown / The feathered hour will not return (p. 15), Swollen with dusk and dust / And hysterical rain (p. 12), The worlds are breaking in my head / blown by the brainless wind (p. 12), The soaring flight of thought beneath the sun (p. 37). These images are multi-dimensional. For example, feathered hour stands for time, quite often metaphorically represented as a bird. But the poet uses two metonymies (feathers for a bird and hour for time) to create a surrealist metaphor. G.D. Martin beautifully clarifies: "The emotional effect of such images is of a chord being struck, rather than of a simple clash between different octaves" (1986, p. 28).

Such images consisting of several interlocking tropes produce an extremely strong effect. Completely metaphoric texture and absence of words in literal meaning in the lines Full-blossoming 
hysterias / Lavishly scattering their stained veined petals create a weird, almost hallucinatory effect: abstract concept hysteria (usually associated with negative, wild or violent psychic forces) is personified (it scatters lavishly) and is given as an analogue of trees full of flowers that 'throw' the petals in random directions. The image is visual, metaphoric and associative.

Surrealist poetry is generally regarded as an apotheosis of metaphor. It should be noted however that not all attributive constructions used metaphorically in David Gascoyne's poetry can be called surrealistic. Some of them are quite common in poetic language: autumn breath of mornings far from here (p. 13), might appear in synesthetic combinations: the fading cries of the light (p. 12), The whispering of unseen flames / A sharp taste in the mouth (p. 14), or in synesthetic contexts: ...And fly away like birds towards the sound of roasting meat (p. 21) - combining auditory, visual and olfactory analogies. They are far less automatic than the images in French surrealist writings of the 1920s. But then, surrealism in England was "less outrageous, less automatic, and more reasonable" (Jackaman, 1975, p. 74).

The hardest for analysis are the images with incongruous lexical items of incompatible semantics. David Gascoyne offers an abundance of poetic lines which show "transformation of the real into the illogic of dreams and hallucinations" (Scott, 2002, p. 71) and which are beyond interpretation: her arms are like pieces of sandpaper / or wings of leprous birds in taxis (2012), Heraldic animals wade through the asphyxia of planets (p. 21). Here we can only join Peter Stockwell who confessed: "By this point my cognitive knowledge is defeated" (Stockwell, 2005, 113). Some images though are clearly the product of the poet's mixing with the artists. And it is familiarity with the surrealists' paintings that can help with the poetic imagery.

For instance, image in attributive construction a flock of banners fight their way through the telescoped forests (p. 21) probably cannot be explained but it actually brings to memory works of Max Ernst who was famous for his frottage and rubbing technique (the artist dropped the paper at random on the boards of the floor and rubbed it with a pencil until the image appeared). His collection of Forests reflects surrealists' desire to delve into the unconscious (forest thus becoming its symbol) in an attempt to meet one's fears, phobias, and obsessions.

Other poetic images: Planetary seed / Sown by the grotesque wind (p. 12) or Awaken the endless desert / Engrossed in its tropical slumber / Enclosed by the dead grey oceans (p. 12) are taken from the poem Yves Tanguy, but even without the title they remind strange phantasmagorical landscapes of the artist. Rene Magritte's love for depicting birds can be heard in the image: The tale of his bright night / And his wing-shadowed day (p. 37). The artistic link thus becomes the basic mechanism for the birth of an image in such adjective-noun constructions.

Influence of surrealism in Gascoyne's poetry is not restricted to artistic motives. Quite common is the poet's appeal to dreams and dream-like states - an essential component of surrealist esthetics: that posture of oblivious dream (p. 8), White sanctuses of sleep / Under the heaped veils / The inexorably prolonged vigils ( $\mathrm{p} .10)$. The latter example seems to be the product of free associations: sunctus, which is a hymn in Christian liturgy, is given a color adjective (audio-visual synesthesia), which might imply the symbolic meanings of the color white or create 'a picture' of the church chorus dressed in white robes while singing. Whether metaphoric reference sanctuses of sleep imply singing over the dead or anything else is really hard to say. In the same way, the context doesn't help to clarify the meaning of attributive combination the inexorably prolonged vigils - whether the poet speaks about "a religious church ceremony at night" or "a period of time at night when you stay awake" (Macmillan) is equally hard to perceive. The distance between the juxtaposed realities seems to be quite big. Rob Jackaman commented that "all of these tactics seem to spring from the common surrealist 'technique of unsettlement', aimed at preventing the reader from feeling at home in the work of art" $(1975$, p. 76$)$. It feels that the only way to read such poetry is to focus on one's personal spontaneous associations and to attempt to make sense of them. 
Another good example of the theme of sleep in David Gascoyne's poetry is a small stanza in the poem Unspoken which presents metaphorically sleep as a place of different colors. Here it is with the original punctuation:

In sleep there are places places

Places overlap

Yellow sleep in the afternoon sunlight

Coming invisibly in through the pinewood door

White sleep wrapped warm in the midwinter

Inhaling the tepid snow

And sleeping in April at night is sleeping in

Shadow as shadow as water and articulate with pain (p. 10).

While there is certain logic in connections like yellow sleep in the sunlight and white sleep in the midwinter, the main mechanism for the image genesis is still the semantic incompatibility of the elements of the combinations: the abstract lexeme sleep acquires color semes and anthropomorphic characteristics of coming and inhaling. Surrealist hypnagogic and hypnopompic states were important means of getting access to the unconscious and hearing its voice. Gascoyne's sleep-stanza and, possible, his journey to the unconscious finishes with shadow, water and articulation of pain. It is composed of predominantly visual images (with an element of tactile modality in the tepid snow) and though it can be easily 'seen' (just like a dream), we can still rely only on individual associations or sensory perceptions while reading.

Finally, one more mechanism of image creation is connected with the sound system of the language. George Mounin somewhat sarcastically describes it as "a disease which afflicts nearly all poets: the belief that certain words have inbuilt universal poetic associations" 1986, p. 6). The critic regards phonetic word-plays as "the empty formalism of technical devices" (Ibid.).

But, to our mind, some interesting images in Gascoyne's poetry develop around sound repetitions. Like in the lines: And a great bird broke loose / Flapping into the silence with strident cries (p. 8). While the first line contains an alliteration of $[b]$ and $[r]$ sounds and short words which create specific rhythm of four spondees in a row, we are more interested in the second line here. It begins with an onomatopoeic lexeme flapping reminding the noise of a bird's wings in motion. Voiceless fricatives [f], [p] somewhat suppress the sonorous [1] (flapping) and further develop into another voiceless fricative sound [s] in the words silence strident. Three repetitions of the diphthong [ai] in a chain of words silence strident cries sound like a real cry of a person or an animal. On the lexical level the sound fabric is created by the progression from the lexeme of the low deaf noise of the wings in the word flapping which breaks the silence and fills it with the sound of extreme volume strident cries.

Even in the limited amount of examples of adjective - noun construction we can observe the additional effect that the phonetic elements produce in the surrealist contexts: alliterations -Cold curtains of rock concealing the bottomless sky (p. 37), A great bird with cruel claws (p. 8), The rainbowcolored barque of pleasure / Brushing the fluid foliage aside (p. 19); assonances - The unchanging programme of its maneuvers / Its rasping grasping claws (p. 18), Lavishly scattering their stained veined petals (p. 10).

Similar sounding words create a melody of the verse but they also serve as an organizing principle of poetry, being, in surrealism at least, sometimes the only link between the two otherwise absolutely incongruous words, like in The fuming future sleeps no more (p. 12), Derision's flimsy feathers (p. 19). The phonetic images that the sounds create are of great importance. And it is especially true when dealing with surrealist's 'plunges' into the unconscious which result in the automatic flow of associations. 
Conclusion. To create surreality, image must conform to rigid criteria of juxtaposing distant realities. Analyses of only one semantic structure of the image - adjective/participle-noun combinations in the poetry of David Gascoyne shows a number of mechanisms the author uses in his works. Though there are a few natural narrative contexts, surreality is born when literal word-combinations occur in strange, incongruous, metaphoric, hallucinatory ambience where they acquire new semantic shades of meaning or in the expressions with the components opposite in meaning or belonging to different semantic groups. The links of meaning or common semes in these word-combinations are hard to find, though it doesn't lead to the destruction of the image but inspires readers' spontaneous associations. The hardest surreal images consist of several interlocking tropes which produce an extremely strong effect or are the product of the poet's contacts with the artists or of his appeal to dreams and psychic states.

Thus, surrealist image remains a complex phenomenon with weird, fantastic, dream-like qualities which is expressed in imagistic language freed from a narrative context. The mechanisms of such image creation in different syntactic constructions may be an interesting object of further study.

\section{REFERENCES}

Гаспаров, М.Л. (2012). Избранные труды. (Том IV). Москва: Языки славянской культуры.

Спасская, Е. Л. (1992). Семантика и структура образа в поэтических текстах франиузских сюрреалистов. (Дисс. канд. филолог. наук). Москва.

Рошаль, В.М. (2008). Энциклопедия символов. Москва: АСТ, Санкт-Петербург: Сова.

Breton, A. (1969). Manifestoes of surrealism. Ann Arbor: University of Michigan Press.

Gascoyne, D. (1936). A Short Survey of Surrealism. Great Britain: Sherval Press.

Germain, E. B. (1986). Automatism and the birth of language. In Higgins I. (Ed.), Surrealism and Language: Seven essays (pp. 76-85). Edinburgh: Scott. acad. Press.

Jackaman, R. (1975). View from the White Cliffs: A Close Look at One Manifestation of English Surrealism. Twentieth Century Literature, 21(1), 72-80.

Jaiocha, A. (2016). The sleep of reason produces surreality. Surrealism in the context of dreams. Magazyn antropologiczno-spoieczno-kulturowy "Maska", 30, 75-85.

Karlinsky, S. (1967). Surrealism in Twentieth-Century Russian Poetry: Churilin, Zabolotskii, Poplavskii. Slavic Review, 26 (4), 605-617.

Martin, G.D. (1986). A measure of distance: the rhetoric of the surrealist adjective. In Higgins I. (Ed.), Surrealism and Language: Seven essays (pp. 12-29). Edinburgh: Scott. acad. press.

Mounin, G. (1986). Paul Eluard's forbidden words. In Higgins I. (Ed.), Surrealism and Language: Seven essays (pp. 1-11). Edinburgh: Scott. acad. press.

Macmillan English Dictionary online. Retrieved from: https:/www.macmillandictionary.com/

Pradivlianna, L. (2019). Dream and Reality in the Poetry of David Gascoigne. Odessa Linguistic Journal, 12, 32-38.

Quinn, S. (1985). Surrealist imagery and the right brain. (PhD), The University of Alberta., Edmonton, Alberta.

Remy, M. (1999). Surrealism in Britain. Aldershot, Hants, England ; Brookfield, Vt.: Ashgate.

Scott, R. L. (2002). David Gascoyne. FromDarkness into Light: A Study of poetry 1932-1950. (PhD), University of Northumbria, Newcastle.

Stockwell, P. (2012). The surrealist experiments with language. In J. Bray (Ed.), The Routledge Companion to Experimental Literature Routledge (pp. 48-61). London, New York: Routledge. Stockwell, P. (2017). The Language of Surrealism. London, Macmillan Int. Higher Education. Stockwell, P. (2005). Cognitive Poetics: An Introduction. London, New York, Routledge. 


\section{LITERARY SOURCES}

Gascoyne, D. (1965). Collected poems. Oxford; New York: Oxford University Press. Gascoyne, D. (2012). Poems. Retrieved from: www.poemhunter.com/poem/and-the-seventhdream- is-the-dream-of-isis/

\section{REFERENCES}

Hasparov, M.L. (2012). Yzbrannыe trudы. (Tom IV). Moskva: Yazыky slavianskoi kulturb.

Spasskaia, E. L. (1992). Semantyka y struktura obraza v poэtycheskykh tekstakh frantsuzskykh siurrealystov. (Dyss. kand. fyloloh. nauk). Moskva.

Roshal, V.M. (2008). Эntsyklopedyia symvolov. Moskva: ACT, Sankt-Peterburh: Sova.

Breton, A. (1969). Manifestoes of surrealism. Ann Arbor: University of Michigan Press.

Gascoyne, D. (1936). A Short Survey of Surrealism. Great Britain: Sherval Press.

Germain, E. B. (1986). Automatism and the birth of language. In Higgins I. (Ed.), Surrealism and Language: Seven essays (pp. 76-85). Edinburgh: Scott. acad. Press.

Jackaman, R. (1975). View from the White Cliffs: A Close Look at One Manifestation of English Surrealism. Twentieth Century Literature, 21(1), 72-80.

Jaiocha, A. (2016). The sleep of reason produces surreality. Surrealism in the context of dreams. Magazyn antropologiczno-spoieczno-kulturowy "Maska", 30, 75-85.

Karlinsky, S. (1967). Surrealism in Twentieth-Century Russian Poetry: Churilin, Zabolotskii, Poplavskii. Slavic Review, 26 (4), 605-617.

Martin, G.D. (1986). A measure of distance: the rhetoric of the surrealist adjective. In Higgins I. (Ed.), Surrealism and Language: Seven essays (pp. 12-29). Edinburgh: Scott. acad. press.

Mounin, G. (1986). Paul Eluards forbidden words. In Higgins I. (Ed.), Surrealism and Language: Seven essays (pp. 1-11). Edinburgh: Scott. acad. press.

Macmillan English Dictionary online. Retrieved from: https://www.macmillandictionary.com/

Pradivlianna, L. (2019). Dream and Reality in the Poetry of David Gascoigne. Odessa Linguistic Journal, 12, 32-38.

Quinn, S. (1985). Surrealist imagery and the right brain. (PhD), The University of Alberta., Edmonton, Alberta.

Remy, M. (1999). Surrealism in Britain. Aldershot, Hants, England ; Brookfield, Vt.: Ashgate.

Scott, R. L. (2002). David Gascoyne. FromDarkness into Light: A Study of poetry 1932-1950. (PhD), University of Northumbria, Newcastle.

Stockwell, P. (2012). The surrealist experiments with language. In J. Bray (Ed.), The Routledge Companion to Experimental Literature Routledge (pp. 48-61). London, New York: Routledge.

Stockwell, P. (2017). The Language of Surrealism. London, Macmillan Int. Higher Education.

Stockwell, P. (2005). Cognitive Poetics: An Introduction. London, New York, Routledge.

Дата надходження до редакиії 08.04.2019 p.

Ухвалено до друку 19.04.2019 p. 